\title{
Dietary preference in dairy calves for feed ingredients high in energy and protein
}

\author{
E. K. Miller-Cushon, ${ }^{*}$ C. Montoro, $†$ I. R. Ipharraguerre, $\neq$ and A. Bach $+\S^{1}$ \\ *Department of Animal and Poultry Science, University of Guelph, Kemptville Campus, 830 Prescott Street, Kemptville, ON, K0G 1J0, Canada \\ †Department of Ruminant Production, IRTA (Institut de Recerca i Tecnologia Agroalimentàries), 08140, Caldes de Montbui, Spain \\ fLucta S.A., 08179 Montornès del Vallès, Spain \\ §Institució Catalana de Recerca i Estudis Avançats (ICREA), 08010 Barcelona, Spain
}

\begin{abstract}
In 3 experiments, we assessed preference of recently weaned dairy calves for (1) 8 high-energy feed types [barley meal, corn meal, corn gluten feed (CGF), oat meal, rice meal, sorghum meal, wheat meal, and wheat middlings meal]; (2) 6 high-protein feed types [corn gluten meal (CGM), wheat distillers dried grains, rapeseed meal, soybean meal (SBM), sunflower meal, and pea meal]; and (3) 4 mixtures (50:50) of the highest- and lowest-ranked high-energy and high-protein feeds, to assess whether calves maintain preference for feed ingredients that are included in a mixture. In all experiments, pairwise preference tests were conducted between all feed types (28 different pairwise preference tests in experiment 1, 15 tests in experiment 2, and 6 tests in experiment 3). Each pairwise preference test was conducted by offering ad libitum access to both feed types for $6 \mathrm{~h}$. All tests were repeated with $20 \mathrm{Hol}-$ stein calves. Before this study, calves were offered milk replacer at a rate of $4 \mathrm{~L} / \mathrm{d}$ and a pelleted starter feed ad libitum. After weaning at $62 \mathrm{~d}$ of age, each calf was involved in a pairwise preference test at 3 and 5 $\mathrm{d}$ postweaning. A preference ratio was calculated for each calf in each test as (intake of feed type A)/(intake of feed type A + intake of feed type B). Preference for feed types was ranked across tests in each experiment using pairwise comparison charts. In experiment 1 , the highest-ranked high-energy feed type was wheat meal and the lowest ranked were rice meal and CGF. In experiment 2, the highest-ranked high-protein feed type was SBM and the lowest ranked was CGM. According to the preference rankings from experiments 1 and 2, experiment 3 evaluated (50:50) mixtures of SBM + wheat meal, SBM + CGF, CGM + wheat meal, and CGM + CGF. The mixture of SBM + wheat meal was highest ranked, CGM + CGF was lowest ranked, and the mixtures containing one high-ranked and one
\end{abstract}

Received June 29, 2013.

Accepted December 1, 2013.

${ }^{1}$ Corresponding author: alex.bach@irta.cat low-ranked feed ingredient (SBM + CGF and CGM + wheat meal) were ranked equally. The results of this study indicate that young calves exhibit clear preferences for certain high-energy and high-protein feeds that may be considered highly palatable. Further, preference ranking of feed types provided as 50:50 mixtures was consistent with ranking of individual feed types, suggesting that palatability of mixed starter rations can be improved by inclusion of a preferred feed type. Key words: dairy calf, feed preference, feed intake, protein, energy

\section{INTRODUCTION}

Encouraging solid feed intake is a key objective of dairy calf management during the milk-feeding stage. Ingestion of solid feed facilitates the transition of the young calf to a functioning ruminant, because fermentation of solid feed stimulates the growth and development of the rumen (Baldwin et al., 2004). Therefore, insufficient solid feed intake may negatively affect weight gain through weaning from milk to solid feed due to compromised digestibility of feed in the rumen (Terré et al., 2007) and to insufficient nutrient intake (Jasper and Weary, 2002; Khan et al., 2007).

Because of the importance of adequate solid feed intake around weaning, it is highly recommended that palatability and acceptability be considered when formulating starter feeds (Morrill and Dayton, 1978; Drackley, 2008). Although some studies to date have investigated the use of flavor additives to encourage solid feed intake (Morrill and Dayton, 1978; Montoro et al., 2011), relatively little research has evaluated the basic preferences of young calves for the variety of feed types commonly used in formulating starter feeds. Bush (1989) offered dairy calves a choice of 4 different starter feeds containing barley, corn, oats, or hull-less oats from 2 to $5 \mathrm{wk}$ of age and reported that calves preferred the barley-based starter feeds. However, these results may not reflect preference for the sensory properties of the feed ingredients, as the starter feeds also differed in nutrient content. Several studies (Matthews and Temple, 
1979; Arave, 1996; Spörndly and Åsberg, 2006) have evaluated preferences for common ration ingredients in adult cattle, but it is not clear whether the results of studies conducted with either mature cows or heifers apply to young calves.

Assessing feed preference in young calves is complicated by the fact that calves have minimal prior feed experience and typically low solid feed intake. Montoro et al. (2012) recently developed and validated a protocol for assessing feed preferences for novel feeds in recently weaned calves. Those authors proposed a model in which pairwise preference tests are conducted for a period of $6 \mathrm{~h}$ in a time window falling $1 \mathrm{~h}$ after peak feeding time. Given a longer period of exposure to feed types, preference for feed types may be influenced by satiety factors and postingestive feedback mechanisms (Provenza, 1995). In comparison, preferences emerging in a 6-h time window may be considered a result of sensory properties of the feed, which are likely to affect initial acceptance by calves offered the feed type early in life (Montoro et al., 2012).

The objectives of this study were, therefore, to assess preference in recently weaned dairy calves for high-energy and high-protein feed types commonly used in formulating starter rations. We hypothesized that preferences for certain protein and energy sources would become apparent, providing an indication of which ingredients may be considered highly palatable for young calves and thus recommended for inclusion in starter feeds. This study also assessed whether preference for particular feed types persists when they are included in the formulation of a ration containing another feed type. We hypothesized that calves would be able to identify feed mixtures containing preferred feed types and, thus, preference of feed mixtures would be consistent with the preference ranking of individual ingredients.

\section{MATERIALS AND METHODS}

\section{Animals and Housing}

A total of 280 female Holstein calves were used in experiment 1, 160 male Holstein calves in experiment 2, and 60 male Holstein calves in experiment 3. Calves were managed under the guidelines and approval of the Animal Care Committee of Institute for Research and Technology in Agrifood (IRTA, Barcelona, Spain). Experiment 1 was conducted at Rancho Las Nieves (Mallén, Spain), and experiments 2 and 3 were conducted at Mas Jonquer (Parets d'Empordà, Spain). All experiments were conducted during a 6 -mo period in fall and winter. During experiment 1 , the average low ambient temperature was $3^{\circ} \mathrm{C}$ and the average high was $13^{\circ} \mathrm{C}$.
Relative humidity ranged from $55 \%$ (average daily low) to $96 \%$ (average daily high). During experiment 2, the average low ambient temperature was $10^{\circ} \mathrm{C}$ and the average high was $23^{\circ} \mathrm{C}$. Relative humidity ranged from $45 \%$ (average daily low) to $96 \%$ (average daily high). For experiment 3, the average low ambient temperature was $3^{\circ} \mathrm{C}$ and the average high was $15^{\circ} \mathrm{C}$. Relative humidity ranged from $46 \%$ (average daily low) to $94 \%$ (average daily high). Photoperiod across all experiments was $10.4 \pm 1.0 \mathrm{~h}$ (mean $\pm \mathrm{SE}$ ). No preference tests were conducted on days where there was precipitation.

Calves in all experiments were housed in individual hutches $(1.0 \times 1.6 \mathrm{~m}$; width $\times$ depth $)$. The interior of each hutch was bedded with straw every $3 \mathrm{~d}$. The front of each hutch had 2 openings $(40 \times 45 \mathrm{~cm})$ for access to 2 plastic pails (capacity $=8 \mathrm{~L}$ ). The pails were horizontally separated by $50 \mathrm{~cm}$ and suspended $60 \mathrm{~cm}$ from the ground by a metal surface $(35 \times 100 \mathrm{~cm})$ with 2 openings. Calves were offered water and a pelleted starter feed (Table 1) ad libitum from birth. The pelleted starter feed was formulated including 12 different ingredients such that the calves had minimal prior exposure to the sensory properties of any individual feed type.

Calves were offered $4 \mathrm{~L} / \mathrm{d}$ of milk replacer (for experiment 1: $25 \% \mathrm{CP}$ and $19.2 \%$ fat, Sprayfo Excellent 60, Sloten BV, Deventer, the Netherlands; for experiments 2 and 3: 24\% CP and 19.5\% fat, Sereno, Celtilait, France) from teat bottles, provided in 2 daily feedings at 0700 and $1900 \mathrm{~h}$ until $55 \mathrm{~d}$ of age. The milk replacer

Table 1. Ingredient and chemical composition of the pelleted starter diet offered from birth until preference tests were conducted

\begin{tabular}{lc}
\hline Item & Value \\
\hline Ingredient, \% of DM & \\
Wheat middlings & 25.2 \\
Corn meal & 19.6 \\
Oat meal & 12.0 \\
Barley meal & 7.03 \\
Corn gluten meal & 7.09 \\
Soybean meal & 5.10 \\
Corn gluten feed & 5.06 \\
Distillers dried grains & 5.00 \\
Wheat meal & 3.02 \\
Sunflower meal & 3.00 \\
Sorghum meal & 2.99 \\
Rice meal & 3.05 \\
Calcium carbonate & 0.87 \\
Sodium chloride & 0.55 \\
Vitamin and mineral premix & 0.44 \\
Chemical composition ${ }^{1}$ & \\
DM, \% & 91.6 \\
CP, \% of DM & 18.9 \\
ADF, \% of DM & 8.61 \\
NDF, \% of DM & 19.5 \\
NFC, \% of DM & 44.4
\end{tabular}

${ }^{1}$ Values were obtained from chemical analysis of the feed ingredients. $\mathrm{NFC}=100-(\% \mathrm{CP}+\% \mathrm{NDF}+\%$ fat $+\%$ ash $)$. 
contained no flavoring agent. From 56 to 62 d of age, calves received $2 \mathrm{~L} / \mathrm{d}$ of milk replacer, offered at $0700 \mathrm{~h}$. No milk was offered after $62 \mathrm{~d}$ of age. At this time, all calves included in the study were evaluated as healthy.

\section{Feed Preference Test}

The feed preference was tested in the present study according to a protocol developed and validated by Montoro et al. (2012) for use in recently weaned calves. Feed preferences were evaluated in each experiment through pairwise preference tests, conducted between all possible pairs of feed types. In each test, the 2 feed types were offered ad libitum for $6 \mathrm{~h}$. As discussed by Montoro et al. (2012), the duration of the test was set to minimize the effect of postingestive consequences on response to feed preferences, as mean ruminal retention time of fluids around weaning is approximately 8 h (Vazquez-Añon et al., 1993). Thus, preferences apparent within the time window over which the test was conducted could be assumed to be a result of taste and palatability preferences, rather than a functional response to nutritional content of the feed (Montoro et al., 2012). Preference tests were conducted at 3 and $5 \mathrm{~d}$ postweaning. Montoro et al. (2012) recommended that the preference tests begin $1 \mathrm{~h}$ after peaks in feeding activity, under the assumption that calves may be more responsive to slight differences in palatability of feed choices when partially satiated. Recently weaned calves have peaks in solid feed intake at times that correspond to milk delivery before weaning (Montoro et al., 2012); therefore, preference tests in the present study were conducted from 0800 to $1400 \mathrm{~h}$.

According to sample size calculations performed by Montoro et al. (2012), analysis of data from 10 to 12 calves would be sufficient to detect differences in pairwise preference tests that are $6 \mathrm{~h}$ in duration. In the present study, each pairwise preference test was repeated with 20 calves to increase the power of the test to detect slight differences in preference.

At $0800 \mathrm{~h}$ on the day of a preference test, the buckets containing the familiar starter feed and water were removed from the front of the hutch and immediately replaced with weighed quantities of the 2 feed types to be evaluated. Although the validation study performed by Montoro et al. (2012) revealed no effect of bucket location on feed intake in pairwise preference tests, the location of the test feeds (right or left) was alternated across all calves in each test as a precaution to minimize any effects of side preference. Water was available ad libitum for the duration of the test in an additional bucket placed on the side of the pen opposite from the solid feed. At $1400 \mathrm{~h}$, the 2 tested feed types were removed, the refused quantities were weighed, and the starter feed was replaced. All tested feed types were ground to pass through a 3-mm mesh using a hammer mill (Nöel-Guy, Bugey, France) to avoid the potentially confounding effects of particle size on feed preference, as well as differentiate the physical form of the tested feed types from the pelleted feed provided from birth. All feed buckets were washed and sanitized before conducting preference tests.

\section{Experiment 1: Preference for Feed Types High in Energy}

In experiment 1 , the preference test protocol described above was used to assess preference for 8 high-energy feed types commonly used to formulate starter feeds for young calves. The high-energy feed types were barley meal, corn meal, corn gluten feed, oat meal, rice meal, sorghum meal, wheat meal, and wheat middlings. The nutrient composition of all tested feed types is reported in Table 2.

To assess preference for the high-energy feeds, 28 pairwise preference tests were conducted involving 280 calves $(65 \pm 0.4 \mathrm{~d}$ of age and $81.9 \pm 1.63 \mathrm{~kg}$ of $\mathrm{BW}$; mean $\pm \mathrm{SD})$. Preference tests were conducted at 3 and $5 \mathrm{~d}$ after weaning. Each preference test involved 20 calves, and each group of 20 calves was randomly assigned to 2 different pairwise preference tests (one conducted at $3 \mathrm{~d}$ postweaning and one at $5 \mathrm{~d}$ postweaning). No calf was exposed twice to the same feed type in any of the preference tests.

\section{Experiment 2: Preference for Feed Types High in Protein}

Experiment 2 was conducted similarly to experiment 1 , but instead tested preference for 6 high-protein feed types commonly used to formulate starter feeds for young calves. The tested feed types were corn gluten meal, pea meal, rapeseed meal, soybean meal, sunflower meal, and wheat dried distillers grains. The nutrient composition of the tested feed types is reported in Table 2.

Feed preferences were evaluated as in experiment 1. To assess preference between all feed types, 15 pairwise preference tests were conducted involving 160 calves $(65 \pm 0.7 \mathrm{~d}$ of age and $79.5 \pm 1.90 \mathrm{~kg}$ of BW; mean \pm SE). Each preference test involved 20 calves, and each group of 20 calves was randomly assigned to 2 different preference tests (one conducted at $3 \mathrm{~d}$ postweaning and one at $5 \mathrm{~d}$ postweaning), except for the final group of 20 calves, which participated in only one preference test conducted at $3 \mathrm{~d}$ postweaning (a second test was not required, because of the uneven number of preference tests to be conducted). 
Table 2. Ingredient and chemical composition ${ }^{1}\left(\%\right.$ of DM) of all tested feed types ${ }^{2}$

\begin{tabular}{|c|c|c|c|c|c|}
\hline \multirow[b]{2}{*}{ Ingredient } & \multicolumn{5}{|c|}{ Chemical composition } \\
\hline & DM & $\mathrm{CP}$ & $\mathrm{NDF}$ & $\mathrm{ADF}$ & NFC \\
\hline \multicolumn{6}{|l|}{ High-energy feeds } \\
\hline Barley meal & 92.1 & 10.6 & 22.7 & 8.75 & 51.7 \\
\hline Corn meal & 89.8 & 8.44 & 13.0 & 3.50 & 62.4 \\
\hline Corn gluten feed & 92.8 & 20.6 & 41.1 & 10.2 & 21.3 \\
\hline Oat meal & 91.9 & 11.7 & 28.3 & 11.6 & 45.1 \\
\hline Rice meal & 93.1 & 7.73 & 3.17 & 0.93 & 80.4 \\
\hline Sorghum meal & 91.3 & 11.4 & 12.3 & 5.75 & 62.1 \\
\hline Wheat meal & 92.4 & 13.0 & 14.1 & 4.34 & 60.2 \\
\hline Wheat middlings & 92.3 & 15.4 & 33.0 & 11.3 & 35.6 \\
\hline \multicolumn{6}{|l|}{ High-protein feeds } \\
\hline Corn gluten meal & 92.8 & 67.4 & 2.23 & 0.56 & 19.2 \\
\hline Distillers dried grains & 88.7 & 27.7 & 21.91 & 8.60 & 30.3 \\
\hline Pea meal & 89.6 & 19.5 & 16.04 & 6.00 & 50.2 \\
\hline Rapeseed meal & 91.2 & 39.3 & 28.36 & 18.2 & 12.9 \\
\hline Soybean meal & 91.1 & 44.8 & 23.14 & 8.29 & 14.5 \\
\hline Sunflower meal & 90.2 & 28.5 & 41.67 & 27.6 & 12.5 \\
\hline
\end{tabular}

\section{Experiment 3: Preference for Mixtures of Corn Gluten Feed, Wheat Meal, Corn Gluten Meal, and Soybean Meal}

According to the results of experiment 1 and experiment 2, the 2 high-energy feed types with the highest and lowest preference rankings and the 2 high-protein feed types with the highest and lowest preference rankings were identified. To assess whether calves maintained their preference for specific ingredients within a mixture, 4 combinations of these feed types, each consisting of one high-energy feed and one high-protein feed, were mixed. The 4 tested mixtures were 50:50 combinations of: corn gluten meal + corn gluten feed, corn gluten meal + wheat meal, soybean meal + corn gluten feed, and soybean meal + wheat meal (see Table $3)$.

To assess preference for the 4 mixed diets, 6 pairwise preference tests were conducted involving 60 calves $(62$ $\pm 1.3 \mathrm{~d}$ of age and $80.9 \pm 2.04 \mathrm{~kg}$ of $\mathrm{BW}$; mean $\pm \mathrm{SE}$ ). Preference tests were conducted as in experiments 1 and 2. Each preference test involved 20 calves, and each group of 20 calves was randomly assigned to 2 different preference tests. Tests were conducted at 3 and $5 \mathrm{~d}$ postweaning, and no calf was presented twice with the same feed mixture.

\section{Feed Analysis}

To determine DM and nutrient content of tested feed types as well as the pelleted starter diet provided from birth, fresh samples were taken of the feed ingredients after grinding, at the time of each preference test. Samples were pooled by feed type across all preference tests (composite samples of 7 samples/feed type in experiment 1 and 5 samples/feed type in experiment 2) and sent to Laboratorio de Mouriscade (Pontevedra, Spain) for analysis of DM $\left(24 \mathrm{~h}\right.$ at $\left.103^{\circ} \mathrm{C}\right)$, ash $\left(4 \mathrm{~h}\right.$ at $\left.550^{\circ} \mathrm{C}\right)$, NDF with heat-stable amylase and sodium sulfite (Van Soest et al., 1991), ADF (AOAC, 1990; method 973.18), $\mathrm{N}$ content (AOAC, 1990; method 988.05), and ether extract (AOAC, 1990; 920.39).

Table 3. Composition of feed mixtures tested in experiment $3^{1}$

\begin{tabular}{|c|c|c|c|c|}
\hline \multirow[b]{3}{*}{ Composition $^{2}$} & \multicolumn{2}{|c|}{ High-protein feed types } & \multicolumn{2}{|c|}{ High-energy feed types } \\
\hline & High rank & Low rank & High rank & Low rank \\
\hline & $\mathrm{SBM}$ & CGM & WM & CGF \\
\hline $\mathrm{SBM}+\mathrm{WM}$ & $50 \%$ & - & $50 \%$ & - \\
\hline $\mathrm{SBM}+\mathrm{CGF}$ & $50 \%$ & - & - & $50 \%$ \\
\hline WM + CGM & - & $50 \%$ & $50 \%$ & - \\
\hline $\mathrm{CGM}+\mathrm{CGF}$ & - & $50 \%$ & - & $50 \%$ \\
\hline
\end{tabular}


On average, across all 6 -h preference tests in which a feed mixture was offered (each mixture was offered in a total of 3 tests), calves consumed $515.8 \pm 72.2 \mathrm{~g}$ of the mixture of soybean meal and wheat meal (mean $\pm \mathrm{SE}$ ), $215.0 \pm 49.0 \mathrm{~g}$ of the mixture of corn gluten meal and wheat meal, $175.6 \pm 30.2 \mathrm{~g}$ of the mixture of soybean meal and corn gluten feed, and $57.2 \pm 16.0$ $\mathrm{g}$ of the mixture of corn gluten meal and corn gluten feed.

\section{Calculations and Statistical Analyses}

To avoid including data from calves with insufficient exposure to the tested feed types, data sets from calves that consumed less than $30 \mathrm{~g}$ over the course of the test were discarded. In the set of 28 pairwise preference tests in experiment 1 , each conducted with 20 calves, data from a total of 3 calves was discarded according to this criterion, leaving an average sample size of $19.9 \pm$ 0.3 calves/pairwise preference test (mean $\pm \mathrm{SE}$ ) with a minimum sample size of 19 calves. In the set of 15 pairwise preference tests evaluating high-protein feeds in experiment 2, data from a total of 13 calves were discarded, leaving an average sample size of $19.1 \pm 1.5$ calves/pairwise preference test (mean $\pm \mathrm{SE}$ ) with a minimum sample size of 15 calves (for the test comparing pea meal and sunflower meal). In experiment 3 , all calves consumed $>30 \mathrm{~g}$ of feed in each preference test, thus no data sets were discarded.

For each calf in each pairwise preference test, preference ratio was calculated as (DMI of feed $\mathrm{A}) /(\mathrm{DMI}$ of feed A + DMI of feed B). Within each pairwise preference test, preference ratios were analyzed for a difference from 0.5 (lack of preference) using $t$-tests within the MIXED procedure of SAS (SAS Institute, 2008).

The effect of test-day (either 3 or $5 \mathrm{~d}$ postweaning) on feed intake was analyzed across all tests in experiments 1 and 2 . Feed intake was summarized by preference test and feed type $(\mathrm{n}=7$ tests/feed type in experiment 1 and $\mathrm{n}=5$ tests/feed type in experiment 2 ). To satisfy assumptions of normality, feed intake was square root transformed. Data were analyzed across all preference tests using PROC MIXED of SAS (SAS Institute, 2008). The model included the random effect of calf within test and the fixed effects of order of exposure (test day), feed type, and order $\times$ feed type interaction.

To compare the results of all pairwise preference tests, results of all tests were compiled into a pairwise comparison chart in each experiment. Pairwise comparison charts are commonly used for global ranking or decision making when multiple pairwise preference tests or comparisons have been made (Dym et al., 2002; Choo and Wedley, 2004). In pairwise compari- son charts, items within a set are ranked on a pair-bypair basis until all permutations have been compared (Dym et al., 2002). In each pairwise comparison, the preferred item is awarded a point and an overall ranking is determined by ordering items according to total points accumulated (Dym et al., 2002). In the current study, the following convention was followed: each feed type was assigned +1 if it was preferred in a pairwise preference test, -1 if it was not preferred in a pairwise preference test, and 0 if the preference ratio in a pairwise preference test did not differ from 0.5 . These preferences scores were summed for all feed types across all pairwise preference tests in which they were tested. Total preference scores were used as an indicator of overall preference rank of individual feed types within each experiment.

\section{RESULTS}

\section{Experiment 1: Preference for High-Energy Feed Types}

Feed intake across all tests were not affected by test day (3 or $5 \mathrm{~d}$ postweaning; $P=0.23$ ) or subject to a feed type $\times$ test day interaction $(P=0.41)$. Feed intake was, however, affected by feed type $(P<0.001)$. On average, across all 6-h preference tests in which a feed type was offered (each individual feed type was offered in a total of 7 tests), calves consumed $448.8 \pm 75.5 \mathrm{~g}$ of wheat meal (mean $\pm \mathrm{SE}$ ), $398.0 \pm 77.3 \mathrm{~g}$ of corn meal, $362.4 \pm 78.9 \mathrm{~g}$ of sorghum meal, $348.2 \pm 46.2 \mathrm{~g}$ of barley meal, $241.6 \pm 45.3 \mathrm{~g}$ of wheat middlings, 168.8 $\pm 31.9 \mathrm{~g}$ of oat meal, $147.8 \pm 44.0 \mathrm{~g}$ of rice meal, and $121.5 \pm 30.6 \mathrm{~g}$ of corn gluten feed.

The results of the pairwise preference tests evaluating high-energy feeds are reported in Table 4. Wheat meal was preferred in all pairwise tests except when compared with corn meal, which was equally preferred. Sorghum meal was preferred over barley meal, corn meal, oat meal, rice meal, and corn gluten feed, and no clear preference was detected between sorghum meal and wheat middlings. Barley meal was preferred over corn meal, oat meal, rice meal, and corn gluten feed, and no clear preference was detected between barley meal and wheat middlings. Corn meal was preferred over wheat middlings, oat meal, rice meal, and corn gluten feed. Oat meal was preferred over wheat middlings but we detected no clear preference between oat meal and rice meal or oat meal and corn gluten feed. Wheat middlings were preferred over rice meal and corn gluten feed. We found no clear preference between rice meal and corn gluten feed. 
Table 4. Total DMI (mean $\pm \mathrm{SE}$ ) and preference ratios for pairwise preference tests conducted using 8 high-energy feed types in experiment $1^{1}$

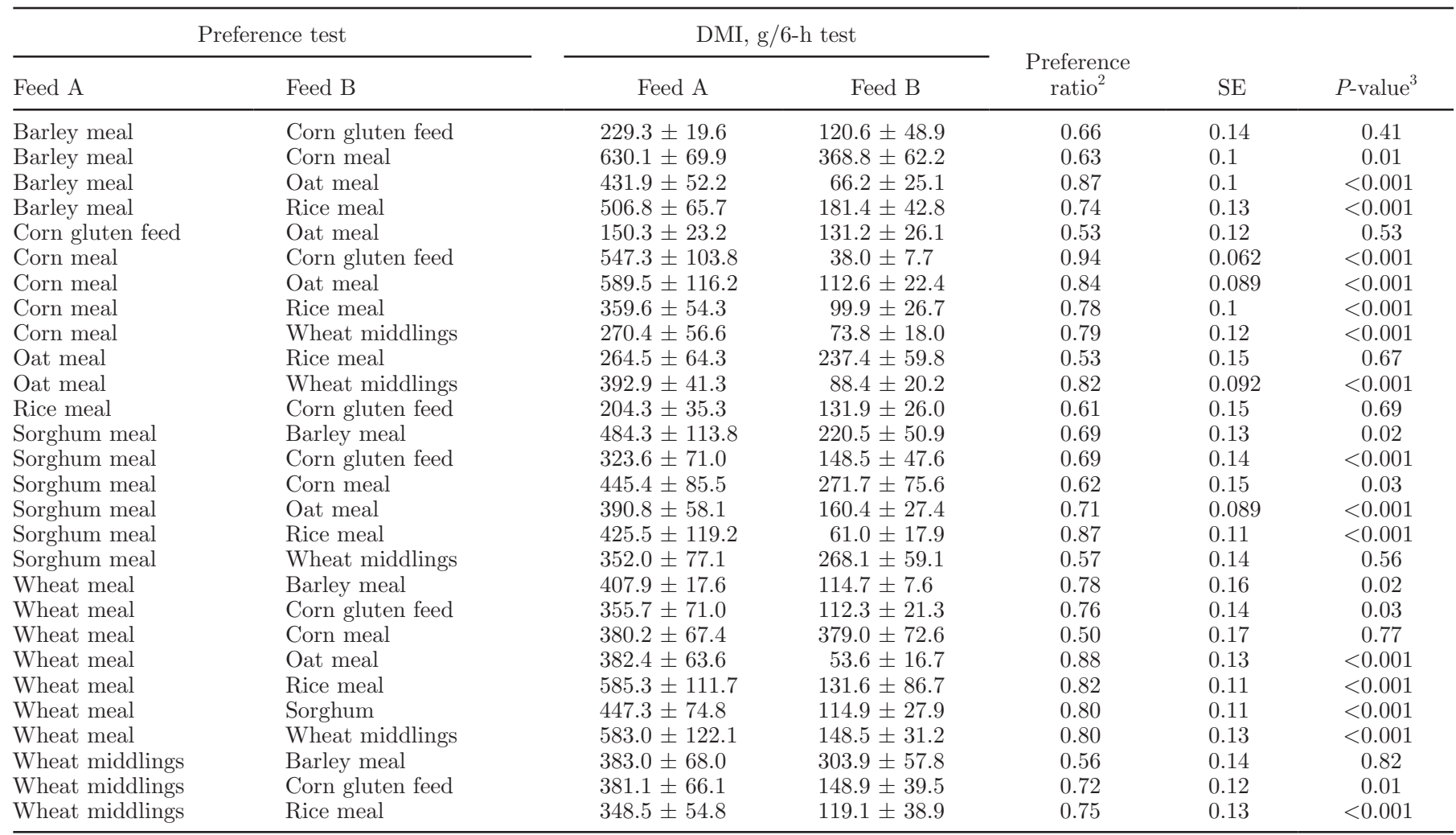

${ }^{1}$ Data averaged across 20 female Holstein calves/test, except for rice meal versus corn gluten feed, sorghum meal versus corn gluten feed, and wheat meal versus rice meal $(\mathrm{n}=19)$.

${ }^{2}$ Preference ratio; calculated as DMI of feed A/(DMI of feed A + DMI of feed B).

${ }^{3}$ Tests whether preference ratio differs from 0.5 .

The results of all pairwise preference tests are summarized in Table 5 using a pairwise comparison chart. According to this method of comparison across all tests, wheat meal was the highest-ranked feed type, followed by sorghum meal. Barley meal and corn meal were equally ranked, falling below wheat meal and sorghum meal but above all other feed types. Corn gluten feed and rice meal were ranked lowest.

\section{Experiment 2: Preference for High-Protein Feed Types}

Feed intake across all tests was not affected by testday ( 3 or $5 \mathrm{~d}$ postweaning; $P=0.62$ ) or subject to a feed type $\times$ test-day interaction $(P=0.33)$. Feed intake was, however, affected by feed type $(P<0.001)$. On average, across all 6 -h preference tests in which a feed

Table 5. Pairwise comparison chart for ranking of preference for high-energy feeds in experiment $1^{1}$

\begin{tabular}{|c|c|c|c|c|c|c|c|c|}
\hline Feed type & $\begin{array}{l}\text { Wheat } \\
\text { meal }\end{array}$ & $\begin{array}{c}\text { Sorghum } \\
\text { meal }\end{array}$ & $\begin{array}{c}\text { Barley } \\
\text { meal }\end{array}$ & $\begin{array}{l}\text { Corn } \\
\text { meal }\end{array}$ & $\begin{array}{l}\text { Wheat } \\
\text { middlings }\end{array}$ & $\begin{array}{l}\text { Oat } \\
\text { meal }\end{array}$ & $\begin{array}{l}\text { Rice } \\
\text { meal }\end{array}$ & $\begin{array}{l}\text { Corn gluten } \\
\text { feed }\end{array}$ \\
\hline Wheat meal & - & -1 & -1 & 0 & -1 & -1 & -1 & -1 \\
\hline Sorghum meal & 1 & - & -1 & -1 & 0 & -1 & -1 & -1 \\
\hline Corn meal & 0 & 1 & 1 & - & -1 & -1 & -1 & -1 \\
\hline Wheat middlings & 1 & 0 & 0 & 1 & - & 1 & -1 & -1 \\
\hline Oat meal & 1 & 1 & 1 & 1 & -1 & - & 0 & 0 \\
\hline
\end{tabular}

${ }^{1}$ Preference was determined as significant using $t$-tests for each pairwise preference test ( $\mathrm{n}=19$ to 20 female Holstein calves/test; Table 4 ). For each pairwise comparison where the preference ratio differed from 0.5 , the preferred feed was assigned 1 and the nonpreferred feed was assigned -1 . For pairwise comparisons that were not significantly different, both feeds were assigned 0 .

${ }^{2}$ Sum of preference scores. 
Table 6. Total DMI (mean \pm SE) and preference ratios for pairwise preference tests conducted using 6 high-protein feed types in experiment $2^{1}$

\begin{tabular}{|c|c|c|c|c|c|c|}
\hline \multicolumn{2}{|c|}{ Preference test } & \multicolumn{2}{|c|}{ DMI, g/6-h test } & $\begin{array}{l}\text { Preference } \\
\text { ratio }^{2}\end{array}$ & $\mathrm{SE}$ & $P$-value ${ }^{3}$ \\
\hline DDG & Corn gluten meal & $361.5 \pm 45.3$ & $64.5 \pm 23.5$ & 0.85 & 0.11 & $<0.001$ \\
\hline DDG & Rapeseed meal & $555.1 \pm 71.3$ & $160.6 \pm 40.2$ & 0.78 & 0.12 & $<0.001$ \\
\hline $\mathrm{DDG}$ & Sunflower meal & $314.9 \pm 27.9$ & $157.3 \pm 39.7$ & 0.67 & 0.11 & $<0.001$ \\
\hline Pea meal & Corn gluten meal & $445.4 \pm 76.5$ & $37.2 \pm 22.4$ & 0.92 & 0.12 & $<0.001$ \\
\hline Soybean meal & DDG & $606.8 \pm 15.5$ & $43.4 \pm 3.81$ & 0.93 & 0.015 & $<0.001$ \\
\hline Soybean meal & Pea meal & $725.4 \pm 164.0$ & $25.3 \pm 3.85$ & 0.97 & 0.08 & $<0.001$ \\
\hline Soybean meal & Rapeseed meal & $563.7 \pm 87.0$ & $10.9 \pm 1.55$ & 0.98 & 0.046 & $<0.001$ \\
\hline Soybean meal & Sunflower meal & $548.7 \pm 44.7$ & $93.4 \pm 20.8$ & 0.85 & 0.062 & $<0.001$ \\
\hline Sunflower meal & Corn gluten meal & $523.9 \pm 51.7$ & $13.5 \pm 5.29$ & 0.97 & 0.015 & $<0.001$ \\
\hline Sunflower meal & Pea meal & $145.9 \pm 39.7$ & $94.4 \pm 33.0$ & 0.61 & 0.2 & 0.32 \\
\hline
\end{tabular}

${ }^{1}$ Data averaged across 20 male Holstein calves/test, except wheat dried distillers grains (DDG) versus rapeseed meal (n = 19), pea meal versus corn gluten meal $(\mathrm{n}=18)$, rapeseed meal versus corn gluten meal $(\mathrm{n}=17)$, soybean meal versus DDG $(\mathrm{n}=19)$, sunflower meal versus pea meal $(\mathrm{n}=15)$, and sunflower meal versus rapeseed meal $(\mathrm{n}=19)$.

${ }^{2}$ Preference ratio; calculated as DMI of feed A/(DMI of feed A + DMI of feed B).

${ }^{3}$ Tests whether preference ratio differs from 0.5 .

type was offered (each individual feed type was offered in a total of 5 tests), calves consumed $605.1 \pm 71.3 \mathrm{~g}$ of soybean meal (mean $\pm \mathrm{SE}$ ), $369.4 \pm 44.8 \mathrm{~g}$ of dried distillers grains, $241.9 \pm 40.5 \mathrm{~g}$ of sunflower meal, 219.1 $\pm 51.5 \mathrm{~g}$ of pea meal, $113.4 \pm 28.8 \mathrm{~g}$ of rapeseed meal, and $30.0 \pm 13.2 \mathrm{~g}$ of corn gluten meal.

The results of the pairwise preference tests evaluating high-protein feeds are reported in Table 6. Soybean meal was preferred in all preference tests. Dried distillers grains were preferred over sunflower meal, rapeseed meal, and corn gluten meal, and no preference was detected between dried distillers grains and pea meal. Sunflower meal was preferred over rapeseed meal and corn gluten meal, and no preference was detected between sunflower meal and pea meal. Pea meal was preferred over corn gluten meal and we found no clear preference between pea meal and rapeseed meal. Rapeseed meal was preferred over corn gluten meal. Corn gluten meal was the less preferred feed type in all comparisons.

The results of all pairwise preference tests are summarized in Table 7 using a pairwise preference test. According to this method of comparison, soybean meal was the highest-ranked feed type, followed by dried distillers grains. Corn gluten meal was the lowest ranked, followed by rapeseed meal.

\section{Experiment 3: Preference for Feed Mixtures}

On average, across all 6 -h preference tests in which a feed mixture was offered (each different mixture was offered in a total of 3 tests), calves consumed $515.8 \pm$

Table 7. Pairwise comparison chart for ranking of preference for high-protein feeds in experiment $2^{1}$

\begin{tabular}{lcccccc}
\hline Feed type & $\begin{array}{c}\text { Soybean } \\
\text { meal }\end{array}$ & $\begin{array}{c}\text { Dried } \\
\text { distillers } \\
\text { grains }\end{array}$ & $\begin{array}{c}\text { Sunflower } \\
\text { meal }\end{array}$ & $\begin{array}{c}\text { Pea } \\
\text { meal }\end{array}$ & $\begin{array}{c}\text { Rapeseed } \\
\text { meal }\end{array}$ & $\begin{array}{c}\text { Corn gluten } \\
\text { meal }\end{array}$ \\
\hline Soybean meal & - & -1 & -1 & -1 & -1 & -1 \\
Dried distillers grains & 1 & - & -1 & 0 & -1 & -1 \\
Sunflower meal & 1 & 1 & - & 0 & -1 & -1 \\
Pea meal & 1 & 0 & 0 & - & 0 & -1 \\
Rapeseed meal & 1 & 1 & 1 & 0 & - & -1 \\
Corn gluten meal & 1 & 1 & 1 & 1 & 1 & -5 \\
$\mathrm{SPi}^{2}$ & 5 & 2 & 0 & 0 & -2 & -5 \\
\hline
\end{tabular}

${ }^{1}$ Preference was determined as significant using $t$-tests for each pairwise preference test $(\mathrm{n}=15-20$ male Holstein calves/test; Table 6). For each pairwise comparison where the preference ratio differed from 0.5, the preferred feed was assigned 1 and the nonpreferred feed was assigned -1 . For pairwise comparisons that were not significantly different, both feeds were assigned 0 .

${ }^{2}$ Sum of preference scores. 
Table 8. Total DMI (mean \pm SE) and preference ratios for pairwise preference tests conducted using four 50:50 feed mixtures in experiment $3^{1}$

\begin{tabular}{|c|c|c|c|c|c|c|}
\hline \multicolumn{2}{|c|}{ Preference test ${ }^{2}$} & \multicolumn{2}{|c|}{ DMI, g/6-h test } & \multirow{2}{*}{$\begin{array}{l}\text { Preference } \\
\text { ratio }^{3}\end{array}$} & \multirow[b]{2}{*}{$\mathrm{SE}$} & \multirow[b]{2}{*}{$P$-value ${ }^{4}$} \\
\hline Mixture A & Mixture B & Mixture A & Mixture B & & & \\
\hline CGM + WM & $\mathrm{CGM}+\mathrm{CGF}$ & $407.0 \pm 93.8$ & $99.0 \pm 29.0$ & 0.80 & 0.081 & $<0.001$ \\
\hline $\mathrm{SBM}+\mathrm{CGF}$ & $\mathrm{CGM}+\mathrm{CGF}$ & $205.3 \pm 32.6$ & $44.2 \pm 9.8$ & 0.82 & 0.058 & $<0.001$ \\
\hline $\mathrm{SBM}+\mathrm{CGF}$ & $\mathrm{CGM}+\mathrm{WM}$ & $237.8 \pm 35.4$ & $191.6 \pm 40.0$ & 0.55 & 0.11 & 0.13 \\
\hline $\mathrm{SBM}+\mathrm{WM}$ & $\mathrm{CGM}+\mathrm{CGF}$ & $654.5 \pm 54.4$ & $28.4 \pm 9.1$ & 0.96 & 0.027 & $<0.001$ \\
\hline $\mathrm{SBM}+\mathrm{WM}$ & $\mathrm{CGM}+\mathrm{WM}$ & $433.4 \pm 75.0$ & $46.3 \pm 13.3$ & 0.90 & 0.11 & $<0.001$ \\
\hline $\mathrm{SBM}+\mathrm{WM}$ & $\mathrm{SBM}+\mathrm{CGF}$ & $459.6 \pm 87.3$ & $83.6 \pm 22.7$ & 0.85 & 0.11 & $<0.001$ \\
\hline
\end{tabular}

${ }^{1}$ Data averaged across $\mathrm{n}=20$ male Holstein calves/test.

${ }^{2} \mathrm{CGF}=$ corn gluten feed; $\mathrm{CGM}=$ corn gluten meal; $\mathrm{SBM}=$ soybean meal; $\mathrm{WM}=$ wheat meal.

${ }^{3}$ Calculated as DMI of mixture A/(DMI of mixture A + DMI of mixture B).

${ }^{4}$ Tests whether preference ratio differs from 0.5 .

$72.2 \mathrm{~g}$ of the mixture of soybean meal and wheat meal (mean $\pm \mathrm{SE}$ ), $215.0 \pm 49.0 \mathrm{~g}$ of the mixture of corn gluten meal and wheat meal, $175.6 \pm 30.2 \mathrm{~g}$ of the mixture of soybean meal and corn gluten feed, and 57.2 $\pm 16.0 \mathrm{~g}$ of the mixture of corn gluten meal and corn gluten feed.

The results of the pairwise preference tests evaluating mixtures of feed types are reported in Table 8. The mixture of soybean meal and wheat meal was preferred in all preference tests. No preferences were detected between the mixture of soybean meal and corn gluten feed and the mixture of corn gluten meal and wheat meal, and both mixtures were preferred over the mixture of corn gluten meal and corn gluten feed.

The results of all pairwise preference tests are summarized in Table 9 using a pairwise preference test. According to this method of comparison, the mixture of soybean meal and wheat meal, which contained both the highest-ranked high-protein feed type and the highest-ranked high-energy feed type, was the highestranked mixture. The mixture of soybean meal and corn gluten feed and the mixture of corn gluten meal and wheat meal, each containing one highest-ranked feed type (soybean meal or wheat meal) and one lowestrank feed type (corn gluten meal or corn gluten feed), were ranked equally below the mixture of soybean meal and wheat meal. The mixture of corn gluten meal and corn gluten feed, which contained the lowest-ranked high-protein and high-energy feed types, was the lowest-ranked mixture. Thus, preference ranking of the mixtures of feed types was consistent with the ranking of individual ingredients.

\section{DISCUSSION}

Much importance is placed on the formulation of rations for dairy calves that are perceived as highly palatable, because solid feed intake early in life facilitates rumen development and predicts performance around the time of weaning (Drackley, 2008). The present study provides evidence that calves have clear preferences for certain ingredients that should thus be considered in the formulation of starter rations.

Of the high-energy ingredients evaluated in experiment 1 , calves showed a consistent preference for wheat meal. In contrast to the present results, Bush (1989) exposed calves to 30 -min preference tests at 2 -wk intervals beginning at $3 \mathrm{wk}$ of age and reported that calves preferred barley over corn, oats, and wheat, and did not discriminate between the latter ingredients. How-

Table 9. Pairwise comparison chart for ranking of preference for feed mixtures in experiment $3^{1}$

\begin{tabular}{lcccc}
\hline Mixture $^{2}$ & $\mathrm{SBM}+\mathrm{WM}$ & $\mathrm{SBM}+\mathrm{CGF}$ & $\mathrm{WM}+\mathrm{CGM}$ & $\mathrm{CGM}+\mathrm{CGF}$ \\
\hline $\mathrm{SBM}+\mathrm{WM}$ & - & -1 & -1 & -1 \\
$\mathrm{SBM}+\mathrm{CGF}$ & 1 & - & 0 & -1 \\
$\mathrm{WM}+\mathrm{CGM}$ & 1 & 0 & -1 & -1 \\
$\mathrm{CGM}+\mathrm{CGF}$ & 1 & 1 & 0 & -3 \\
$\Sigma \mathrm{Pi}^{3}$ & 3 & 0 & 0 \\
\hline
\end{tabular}

${ }^{1}$ Preference was determined as significant using $t$-tests for each pairwise preference test $(\mathrm{n}=20$ male Holstein calves/test). For each pairwise comparison where the preference ratio differed from 0.5 , the preferred feed was assigned 1 and the nonpreferred feed was assigned -1 . For pairwise comparisons that were not significantly different, both feeds were assigned 0.

${ }^{2} \mathrm{CGF}=$ corn gluten feed; $\mathrm{CGM}=$ corn gluten meal; $\mathrm{SBM}=$ soybean meal; $\mathrm{WM}=$ wheat meal.

${ }^{3} \mathrm{Sum}$ of preference scores. 
ever, preference for barley may have been confounded by familiarity with this feed type, because calves were provided a barley-based starter feed between preference tests. Of the high-energy feed types tested in the present study, corn gluten feed and rice meal were not preferred in any pairwise preference test. Interestingly, rice meal is considered a highly palatable ingredient for piglets (Solà-Oriol et al., 2009) but, to our knowledge, no studies to date have investigated preference for rice meal in cattle. It is worth noting that the starter pellet to which calves were exposed before weaning contained a greater quantity of wheat middlings $(25.2 \%$ of DM) than other tested feed ingredients. The starter pellet was formulated containing a wide range of feed ingredients (Table 1) to limit the extent to which calves could discriminate individual flavors and sensory properties of feed ingredients, as the novelty of feed types may affect dietary choice (Provenza and Balph, 1988). Although wheat middlings were not highly ranked in order of preference (Table 5), it is possible that this degree of preference was affected in some way by the starter feed provided. Wheat meal, however, was most preferred and was included in the starter feed at only $3 \%$ of DM, suggesting that the starter feed formulation had little influence on identification of most- and leastpreferred ingredients.

The results of experiment 2 indicate that soybean meal is a highly palatable protein source for dairy calves, whereas rapeseed meal and corn gluten meal are less preferred. It has been reported previously that soybean meal is preferred over rapeseed meal in lambs and calves (Stedman and Hill, 1987). Additionally, replacing soybean meal with rapeseed meal in a ration for steers was found to result in a linear decrease in feed intake (Lardy and Kerley, 1994). High concentrations of glucosinolates in rapeseed meal are thought to cause a taste aversion, resulting in low palatability (Lardy and Kerley, 1994). However, in contrast to the present results, cattle have been found to prefer rapeseed meal over soybean meal in a longer-term study (Bertilsson et al., 1994) and in repeated 2-h choice tests (Spörndly and Åsberg, 2006).

Perception of feed palatability is considered a consequence of both innate hedonic value of certain sensory properties of food and learned associations of postingestive feedback with properties of food, especially taste and smell in ruminants (Provenza et al., 1992; Forbes, 2007). Cattle appear to possess innate preferences for sweet and umami flavors over bitter flavors (Nombekela et al., 1994; Ginane et al., 2011). These innate preferences may serve an evolutionary function in the avoidance of toxins and selection of nutrients (Forbes, 2007; Ginane et al., 2011). For example, calves may avoid rapeseed meal in response to the bitter flavor of glucosinolates (Lardy and Kerley, 1994). Preference for umami flavor may have evolved because this taste is commonly triggered by amino acids, which indicate the presence of protein, whereas sweet flavor may be preferred because it indicates the presence of carbohydrates (Ginane et al., 2011). Therefore, feed types perceived as highly palatable in the present study, such as soybean meal, likely contain greater quantities of sensory compounds with high hedonic value. Further research is encouraged to investigate factors motivating preference in dairy calves and to identify sensory compounds that may be associated with palatability and, therefore, encourage intake.

Whereas sensory properties of feeds may influence short-term diet selection (Ginane et al., 2011; FavreauPeigné et al., 2013), the association of feed characteristics with positive or negative postingestive feedback can strongly influence feed preferences and aversions (Burritt and Provenza, 1989; Villalba and Provenza, 1997). Thus, inconsistencies across the literature in preference of feed ingredients are likely due to differences in the age and previous experience of the animals, as well as variation in the methodology for assessing preference. Feed preference tests that are repeated or conducted over a long period are likely to yield results that differ from short-term studies, in which the initial response to feed sensory properties is evaluated. Spörndly and Åsberg (2006) reported that the extent of a preference for barley exhibited by heifers changed over repeated choice tests. In addition, feed preferences of mature animals are subject to previous experience (Arnold and Maller, 1977; Nolte et al., 1990), and therefore may differ from preferences of naïve calves.

It is possible that initial dietary choices of young calves are primarily influenced by sensory properties, because low solid feed intake in conjunction with milk intake may confuse the association of solid feed properties with postingestive feedback (Duncan and Young, 2002). This possibility is supported by evidence that feed intake of young calves is affected by changes in sensory properties of the feed in the absence of changes to nutrient content and, consequently, postingestive feedback: solid feed intake in young calves has been increased through addition of the same flavor additive to solid feed and milk (Morrill and Dayton, 1978; Montoro et al., 2011) as well as addition of monosodium glutamate, an umami flavor additive (Waldern and van Dyk, 1971). It was the aim of the present study to evaluate preference for feed types on the basis of sensory properties alone. Thus, these results reflect how feed types may vary in initial acceptability when presented to young calves and, consequently, affect initial intake when included in starter rations. 
In experiment 3, when the highest- and lowest-ranked feed types from experiments 1 and 2 were offered as 50:50 mixtures, the preference ranking of the mixed diets was consistent with the ranking of individual ingredients. Thus, perceived palatability of the mixed diets appeared to be a direct result of the palatability of individual ingredients, as mixtures containing one high-ranked and one low-ranked ingredient were equally ranked below mixtures containing only high-ranked ingredients and above low-ranked ingredients (Table 9). Interestingly, Stone and Wood (1973) reported that replacing up to $50 \%$ of the soybean meal in a calf starter ration with rapeseed meal did not affect intake, but that intake and weight gain were negatively affected when $100 \%$ of the soybean meal was replaced with rapeseed meal. Similarly, it has been reported that DMI of adult cattle is not affected by inclusion of corn gluten feed in the mixed ration at a rate of $36 \%$ (Armentano and Dentine, 1988) or $45 \%$ of total DM (Schroeder, 2003). The present results suggest that addition of a preferred feed type to a starter ration may minimize negative effects of any less-palatable ingredients.

\section{CONCLUSIONS}

The results of the preference tests conducted in this study provide an indication of how recently weaned dairy calves perceive the palatability of a variety of high-energy and high-protein feed types that are commonly included in the formulation of calf starter feeds. Wheat meal and sorghum meal may be considered highly palatable energy sources, whereas rice meal and corn gluten feed are least preferred. In the evaluation of high-protein feed types, soybean meal and dried distillers grains were the highest ranked, whereas rapeseed meal and corn gluten meal were least preferred. Preferences for the highest-ranked protein and energy ingredients were maintained when these feed types were included at a rate of $50 \%$ of a mixed diet. Thus, palatability and acceptability of calf starter feeds may be improved by the inclusion of the highly ranked energy and protein sources identified in this study.

\section{ACKNOWLEDGMENTS}

Financial support from the Spanish National Institute for Agriculture and Food Research and Technology (INIA) for the research assistantship of Carlos Montoro is acknowledged. Emily Miller-Cushon was supported by a Natural Sciences and Engineering Research Council of Canada (NSERC) Michael Smith Foreign Study Supplement.

\section{REFERENCES}

AOAC. 1990. Official Methods of Analysis. 15th ed. Assoc. Off. Anal. Chem., Arlington, VA.

Arave, C. W. 1996. Assessing sensory capacity of animals using operant technology. J. Anim. Sci. 74:1996-2009.

Armentano, L. E., and M. R. Dentine. 1988. Wet corn gluten feed as a supplement for lactating dairy cattle and growing heifers. J. Dairy Sci. 71:990-995.

Arnold, G. W., and R. A. Maller. 1977. Effects of nutritional experience in early and adult life on the performance and dietary habits of sheep. Appl. Anim. Ethol. 3:5-26.

Baldwin, R. L., K. R. McLeod, J. L. Klotz, and R. N. Heitmann. 2004. Rumen development, intestinal growth and hepatic metabolism in the pre- and post-weaning ruminant. J. Dairy Sci. 87:E55-E65.

Bertilsson, J., M. Emanuelson, and M. Murphy. 1994. Linseed products for dairy cows. Report 229, Dept. Anim. Nutr. Management, Swedish Univ. Agric. Sci., Uppsala, Sweden.

Burritt, E. A., and F. D. Provenza. 1989. Food aversion learning: Ability of lambs to distinguish safe from harmful foods. J. Anim. Sci. 67:1732-1739.

Bush, R. S. 1989. Preference among different grains expressed by young Holstein calves. Can. J. Anim. Sci. 69:1099-1103.

Choo, E. U., and W. C. Wedley. 2004. A common framework for deriving preference values from pairwise comparison matrices. Comput. Oper. Res. 31:893-908.

Drackley, J. K. 2008. Calf nutrition from birth to breeding. Vet. Clin. North Am. Food Anim. Pract. 24:55-86.

Duncan, A. J., and S. A. Young. 2002. Can goats learn about foods through conditioned food aversions and preferences when multiple foods are simultaneously available? J. Anim. Sci. 80:2091-2098.

Dym, C. L., W. H. Wood, and M. J. Scott. 2002. Rank ordering engineering designs: Pairwise comparison charts and borda counts. Res. Eng. Design 13:236-242.

Favreau-Peigné, A., R. Baumont, and C. Ginane. 2013. Food sensory characteristics: Their unconsidered roles in the feeding behaviour of domestic ruminants. Animal 7:806-813.

Forbes, J. M. 2007. Voluntary Food Intake and Diet Selection in Farm Animals. 2nd ed. CABI, Cambridge, MA.

Ginane, C., R. Baumont, and A. Favreau-Peigné. 2011. Perception and hedonic value of basic tastes in domestic ruminants. Physiol. Behav. 104:666-674.

Jasper, J., and D. M. Weary. 2002. Effects of ad libitum milk intake on dairy calves. J. Dairy Sci. 85:3054-3058.

Khan, M. A., H. J. Lee, W. S. Lee, H. S. Kim, S. B. Kim, K. S. Ki, J. K. Ha, H. G. Lee, and Y. J. Choi. 2007. Pre- and postweaning performance of Holstein female calves fed milk through step-down and conventional methods. J. Dairy Sci. 90:876-885.

Lardy, G. P., and M. S. Kerley. 1994. Effect of increasing the dietary level of rapeseed meal on intake by growing beef steers. J. Anim. Sci. 72:1936-1942.

Matthews, L. R., and W. Temple. 1979. Concurrent schedule assessment of food preference in cows. J. Exp. Anal. Behav. 32:245-254

Montoro, C., F. Boe, I. R. Ipharraguerre, and A. Bach. 2012. Development of a method to evaluate oro-sensory preferences in weaned calves. Livest. Sci. 150:374-380.

Montoro, C., I. Ipharraguerre, and A. Bach. 2011. Effect of flavoring a starter in a same manner as a milk replacer on intake and performance of calves. Anim. Feed Sci. Technol. 164:130-134.

Morrill, J. L., and A. D. Dayton. 1978. Effect of feed flavor in milk and calf starter on feed consumption and growth. J. Dairy Sci. 61:229-232.

Nolte, D. L., F. D. Provenza, and D. F. Balph. 1990. The establishment and persistence of food preferences in lambs exposed to selected foods. J. Anim. Sci. 68:998-1002.

Nombekela, S. W., M. R. Murphy, H. W. Gonyou, and J. I. Marden. 1994. Dietary preferences in early lactation cows as affected by primary tastes and some common feed flavors. J. Dairy Sci. 77:2393-2399. 
Provenza, F. D. 1995. Postingestive feedback as an elementary preference and intake in ruminants determinant of food. J. Range Manage. 48:2-17.

Provenza, F. D., and D. F. Balph. 1988. Development of dietary choice in livestock on rangelands and its implication for management. J. Anim. Sci. 66:2356-2368.

Provenza, F. D., J. A. Pfister, and C. D. Cheney. 1992. Mechanisms of learning in diet selection with reference to phytotoxicosis in herbivores. J. Range Manage. 45:36-45.

SAS Institute. 2008. SAS User's Guide. Version 9.2. SAS Institute Inc., Cary, NC.

Schroeder, J. W. 2003. Optimizing the level of wet corn gluten feed in the diet of lactating dairy cows. J. Dairy Sci. 86:844-851.

Solà-Oriol, D., E. Roura, and D. Torrallardona. 2009. Feed preference in pigs: Effects of cereal sources at different inclusion rates. J. Anim. Sci. 87:562-570.

Spörndly, E., and T. Åsberg. 2006. Eating rate and preference of different concentrate components for cattle. J. Dairy Sci. 89:21882199

Stedman, J. A., and R. Hill. 1987. Voluntary food intake in a limited time of lambs and calves given diets containing rapeseed meal from different types and varieties of rape, and rapeseed meal treated to reduce the glucosinolate concentration. Anim. Prod. 44:75-82.

Stone, J. B., and A. S. Wood. 1973. Rapeseed meal as a protein source in the starter concentrate for replacement calves. Can. J. Anim. Sci. 53:327-332.

Terré, M., M. Devant, and A. Bach. 2007. Effect of level of milk replacer fed to Holstein calves on performance during the preweaning period and starter digestibility at weaning. Livest. Sci. 110:82-88.

Van Soest, P. J., J. B. Robertson, and B. A. Lewis. 1991. Methods for dietary fiber, neutral detergent fiber, and nonstarch polysaccharides in relation to animal nutrition. J. Dairy Sci. 74:3583-3597.

Vazquez-Añon, M., A. J. Heinrichs, J. M. Aldrich, and G. A. Varga. 1993. Postweaning age effects on rumen fermentation end-products and digesta kinetics in calves weaned at 5 weeks of age. J. Dairy Sci. 76:2742-2748.

Villalba, J. J., and F. D. Provenza. 1997. Preference for wheat straw by lambs conditioned with intraruminal infusions of starch. Br. J Nutr. 77:287-297.

Waldern, D. E., and R. D. van Dyk. 1971. Effect of monosodium glutamate in starter rations on feed consumption and performance of early weaned calves. J. Dairy Sci. 54:262-265. 